\title{
LUMBOPELVIC FIXATION: A SURGICAL ALTERNATIVE FOR LUMBAR STABILITY
}

\author{
FIXAÇÃO LOMBOPÉLVICA: ALTERNATIVA CIRÚRGICA PARA A ESTABILIDADE LOMBAR \\ FIJACIÓN LUMBOPÉLVICA: UNA ALTERNATIVA QUIRÚRGICA EN LA ESTABILIDAD LUMBAR
}

Gabriel Virgilio Ortiz García ${ }^{1}$, Rodolfo Ortiz Soto ${ }^{1}$, Enrique Vargas Uribe ${ }^{1}$, José María Jiménez Avila ${ }^{1}$

\begin{abstract}
Objective: Lumbopelvic fixation is a valid surgical option to achieving great stability in cases where it is particularly demanded, such as in patients with poor quality bone, degenerative scoliosis, and revision surgeries with modern materials and techniques. It enables simple integration of the iliopelvic systems with the rest of the spinal structure, maintaining hemorrhagia at acceptable levels, as well as surgery time. Methods: We analyzed a case series of 15 patients of our center, who required major construction and/or presented poor quality bone. Results: A total of 15 patients was studied, of which 12 (80\%) were women and three (20\%), men. Nine (60\%) of these were revision surgeries, maintaining a surgery time of 5 hours $( \pm 1 \mathrm{~h})$, with average blood loss of $1380 \mathrm{ml}( \pm 178 \mathrm{ml})$. All the patients received six to eight transpedicular screws, including iliac screws, and in all cases, a bone graft was inserted. Conclusion: Lumbopelvic fixation in patients with characteristics associated with osteopenia and osteoporosis, and in major instrumentations, particularly revision surgeries, three-dimensional correction is achieved, constructing a strong, stable pelvic base that is very useful, in patients with fragile surgical anatomy, for changes of implant or extensive decompression, provided the arthrodesis technique is adequate and with the insertion of a sufficient bone graft, and obviously, taking care to maintain the sagittal balance.
\end{abstract}

Keywords: Vertebral fusion; Pelvic bones; Bone malalignment/surgery.

\section{RESUMO}

Objetivo: A fixação lombopélvica é uma opção cirúrgica válida para se atingir grande estabilidade nos casos em que ela é particularmente exigida, como em pacientes com má qualidade óssea, escoliose degenerativa e cirurgias de revisão com os materiais e técnicas modernas, e permite a integração simples dos sistemas iliopélvicos ao restante da estrutura espinal, mantendo a hemorragia em taxa aceitável, assim como o tempo de cirurgia. Métodos: Analisamos uma série de casos de 15 pacientes de nosso centro, que exigiam grande construção e/ou apresentavam má qualidade óssea. Resultados: Foi estudado um total de 15 pacientes, dos quais 12 (80\%) eram mulheres e tres (20\%), homens. Nove (60\%) dessas cirurgias foram de revisão, mantendo-se o tempo cirúrgico de 5 horas ( \pm 1 h), com média de perda de sangue de $1380 \mathrm{ml}( \pm 178 \mathrm{ml})$. Todos os pacientes receberam de seis a oito parafusos transpediculares, inclusive ilíacos e, em todos os casos, colocou-se enxerto ósseo. Conclusão: A fixação lombopélvica em pacientes com características associadas de osteopenia e osteoporose e nas instrumentações grandes, sobretudo nas cirurgias de revisão, atinge correção tridimensional, construindo base pélvica forte e estável, muito útil para os pacientes cuja anatomia cirúrgica é frágil ao se realizarem trocas de implante ou descompressão extensa, desde que a técnica de artrodese seja adequada e com colocação de enxerto ósseo suficiente e, evidentemente, com o cuidado de manter o equilíbrio sagital.

Descritores: Fusão vertebral; Ossos pélvicos; Mau alinhamento ósseo/cirurgia.

\section{RESUMEN}

Objetivo: La fijación lumbopélvica es una opción quirúrgica válida para adquirir gran estabilidad en casos donde es especialmente requerido, como pacientes con pobre calidad ósea, escoliosis degenerativa y cirugías de revisión con los materiales y técnicas actuales y permite una integración sencilla de los sistemas iliopélvicos al resto de la construcción espinal, manteniendo un sangrado en rango aceptable así como el tiempo quirúrgico. Métodos: Analizamos una serie de casos de 15 pacientes de nuestro centro en donde se requería una construcción larga y/o presentaban pobre calidad ósea. Resultados: Se estudió un total de 15 pacientes de los cuales 12 (80\%) fueron del sexo femenino y tres (20\%) del sexo masculino. El nueve (60\%) fueron cirugías de revisión y se mantuvo un tiempo quirúrgico de 5 horas ( \pm 1 hora), con sangrado promedio de $1380 \mathrm{ml}( \pm 178 \mathrm{ml})$. A todos se les colocó seis a ocho tornillos transpediculares incluyendo iliacos y en todos los casos se coloco injerto óseo. Conclusión: La fijación lumbopélvica en pacientes con características asociadas de osteopenia y osteoporosis y en las instrumentaciones largas, sobre todo cirugía de revisión, logra una corrección tridimensional, construyendo una base pélvica potente y estable, muy útil en pacientes en donde la anatomía quirúrgica queda endeble al realizar cambios de implantes o descompresión extensa, siempre y cuando la técnica de la artrodesis sea adecuada y con aporte suficiente de injerto óseo, y evidentemente con el cuidado de mantener el balance sagital.

Descriptores: Fusión vertebral; Huesos pélvicos; Desviación ósea/cirugía.

\section{INTRODUCTION}

Lumbopelvic fixation is a valid option for caudal fixation in multi-segment spinal structures, and is important due to the biomecha- nical demands of the caudal extremity. ${ }^{1}$

This type of fixation depends on the biomechanical demand, the anatomy of the bone anchor points, and the bone quality. (Figure 1)

1. Centro Médico Puerta de Hierro Zapopan, Jalisco, Mexico.

Study conduct at Spine Specialist Centro Médico Puerta de Hierro Zapopan, Jalisco, Mexico.

Correspondence:Torre Médica Elite. Centro Médico Puerta de Hierro. Av. Empresarios, 150. Colonia Puerta de Hierro. 45116, Zapopan, Jalisco. Mexico. virgilio.ortiz@me.com; josemajimeneza@ hotmail.com 


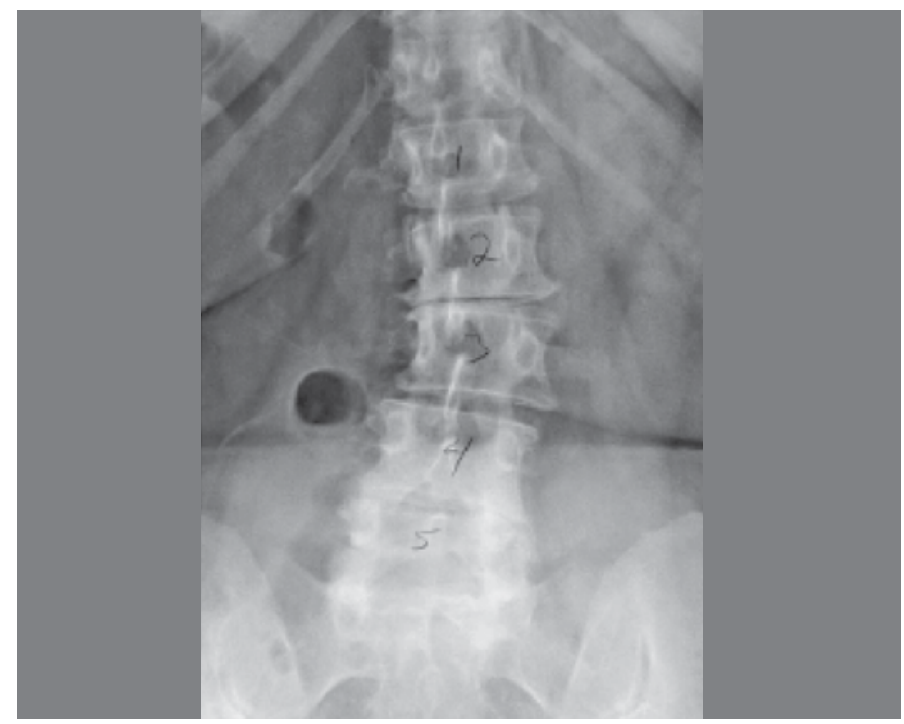

Figure 1. Simple X-ray of patient with degenerative scoliosis.

It is extremely important to bear in mind factors such as osteoporosis, as these have an effect on the ability of the bone-metal interface to support the "cantilever" forces present at the caudal extremity of the spinal structure. ${ }^{1.2}$

The need for a stable caudal fixation in the restoration, and the maintenance of sagittal balance, require the spine surgeon to have a mastery of the whole range of techniques available for caudal fixation. ${ }^{4}$

It is important to bear in mind that the sacrum is the most caudal segment of the spine, and is comprised mainly of cancellous bone, with cortical margins, therefore the anterior and superior margins of S1 provide the largest area for the fixation. ${ }^{5}$

The anteroposterior diameter of the sacrum decreases 45-50 $\mathrm{mm}$ cephalad and 20 to $3 \mathrm{~mm}$ distally. The bone is thicker in the midline and side ala, and the five fused sacral vertebrae of the sacrum transmit the load from the spine to the pelvis and legs. ${ }^{6}$

When the decision is made to insert an iliac screw, take advantage by starting in the posterosuperior iliac spine, moving toward its previous counterpart, avoiding the sciatic notch.

The sacrum and pelvis can be divided into three zones, both from an anatomical point of view, and also in terms of the instrumentation; zone 1 includes the vertebral body of S1 and the cephalic margins of the ala.

The pedicle screws of S1 are used here, and should converge to the midline, with a bicortical or tricortical point; zone 2 is the ala and extends from S2 to S5. ${ }^{6}$

The bone quality and neural anatomy restrict the fixation options in this area, therefore ala screws or foraminal hooks have been used in addition to the $\mathrm{S} 1$ pedicle screws. Fixation in this zone will only add $20 \%$ to $30 \%$ of fixation to zone 1 (pedicle screw of $\mathbf{S 1}$ ). Zone 3 is the llium, and is biomechanically the most efficient anchorage area. ${ }^{6}$

The iliac screws are ideal through a long oblique extension of bone on the sciatic notch. The iliac screws may be from 7.5 to 10 $\mathrm{mm}$ in diameter and 70 to $90 \mathrm{~mm}$ in length, which can reduce the tension of the S1 screw.

The sacral instrumentation is subject to great flexion forces, therefore the specific type and placement of this instrumentation is important.

It is important to consider the biological environment where the graft is to be placed, as it must be an ideal surface to promote fusion, in this area that has a high risk of non-union. ${ }^{7}$ (Figure 2)

It is important to select the type of patient, for example when the instrumentation extends above L2, the tension of the cantilever can exceed the capacity of the sacral fixation to resist fatigue, even with the addition of intersomatic systems. ${ }^{8}$

The caudal fixation is performed in the lumbar pedicles, which provide a tube of cortical bone that allows the pedicle screw to grip. This is the primary area of extrusion force and load resistance of these implants. The grip in cancellous bone is a much more limited contribution, therefore it requires longer screws. ${ }^{9}$

Specifically in the sacral fixation, due to its unique anatomy, the sacral pedicles mix with the material of its triangular structure, and as the result, the sacrum does not have the distinctive long tube of cortical bone that is present in the lumbar pedicles. There is no grip of the pedicle screw along a tube of cortical bone to provide strength, lacking the cortical tube of the pedicle screws. The sacral screws require bicortical grip if they are to be effective anchor points. Without the bicortical grip, the screw can work lose within the unicortical grip and the vast bed of cancellous bone that provides little resistance. This is exacerbated in situations of osteoporosis, due to the loss of the cancellous trabeculae. That is why the sacral pedicle screws should be fixed in the anterior and in the posterior cortical bone of $\mathrm{S} 1$, to be effective, as this is the area with thicker cortical bone in the sacrum and the area that provides the best mechanical grip. ${ }^{6.10}$

The evaluation of grip is considered tricortical, because the screw in this zone grips the anterior and posterior cortical and bone elements of the terminal plate, giving it a certain mechanical advantage. ${ }^{5.8}$ (Figure 3)

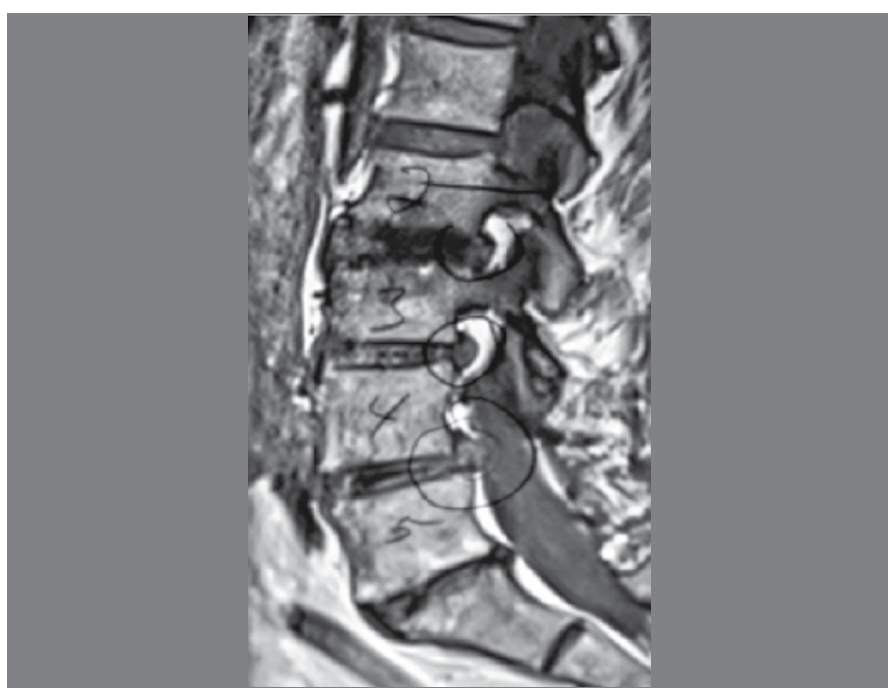

Figure 2. MRI of patient requiring a comprehensive decompression that needed long instrumentation, opting for a lumbopelvic fixation.

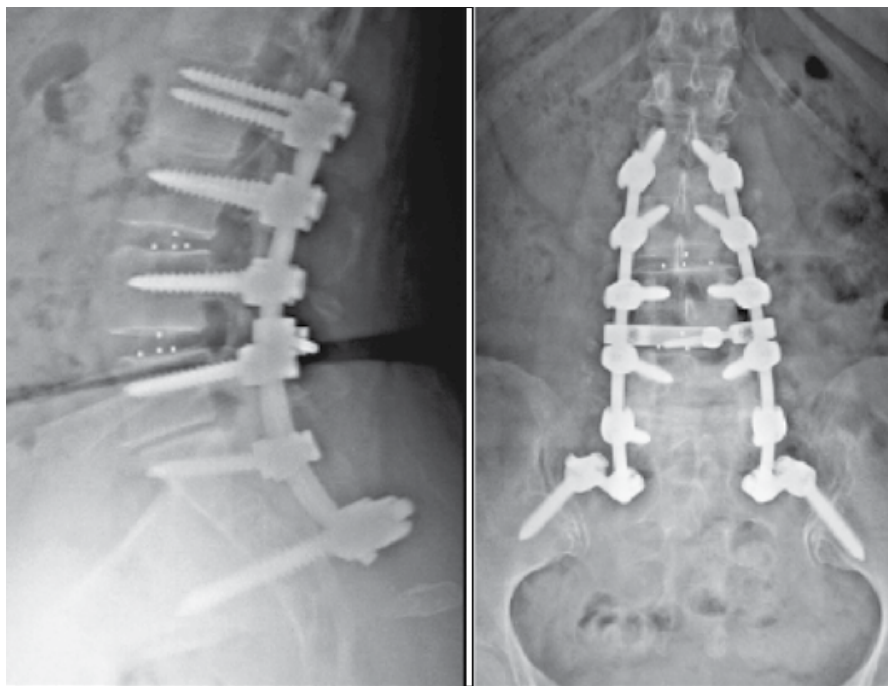

Figure 3. Postsurgical radiographic result of lumbopelvica fixation in which a tricortical fixation is observed. 


\section{MATERIAL AND METHODS}

A case study was carried out, which included patients diagnosed with degenerative pathology of the lumbar spine, and who were candidates for the placement of a lumbopelvic fixation, who met the inclusion criteria, and specifically, who had osteoporosis, severe degenerative scoliosis, large constructions in osteopenic patients, review of syndrome in failed surgery, and other abnormalities involving the sacrum (myelomeningocele, cerebral palsy).

A data capture form was developed which contained all the medical register data, as well as the risk factors (use of alcohol, tobacco, drugs), surgery-related factors (date of surgery, diagnosis, surgical time, bone quality, transpedicular graft, graft used, site of the graft placement, type of instrumentation used, number of screws used, decompression of spinal canal, intraoperative and postoperative complications. This work does not require approval by the ethics committee, but each case is authorized, through an informed consent form, in relation to the use of the data obtained.

\section{RESULTS}

We studied a total of 15 patients in the period January 2009 to August 2010. Of these, 12 (80\%) were female and three (20\%) male. The patients' histories included positive alcoholism in $10 \mathrm{ca}-$ ses (66\%) and negative alcoholism in five cases (34\%). None had a history of drug use, and smoking was also negative. There were six cases $(40 \%)$ with a diagnosis of spondylolisthesis, four (27\%) with lumbar canal narrow, four (27\%) with lumbar herniated disc and one (6\%) with degenerative scoliosis; the average age was 57 years with a SD of nine and weight of SD of 94 . A total of $30.9(60 \%)$ had previous surgical history and 6 (40\%) did not; all the patients underwent transpedicular instrumentation with six to eight screws including both iliacs, and also all of them received a bone graft. (Figure 4).

The approximate surgery time was 5 hours, SD 1 and there was average bleeding of 1380, SD 178. (Table 1).

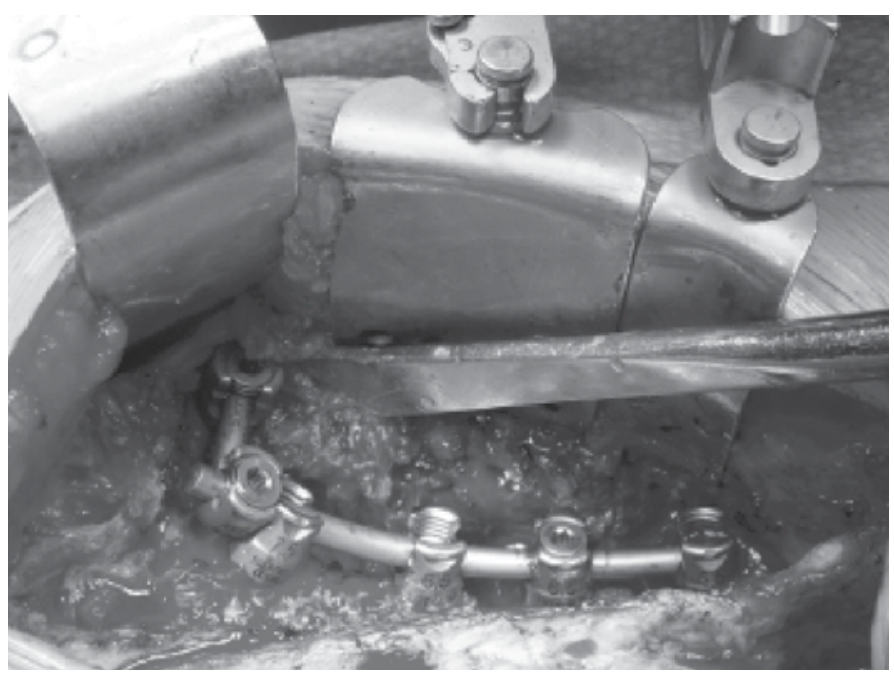

Figure 4. Transsurgical photograph of a construction through lumbopelvic fixation. Note the rod connecting to the iliac screw.

\section{DISCUSSION}

Iliac fixation techniques have evolved. Initially, Harrington placed a threaded rod transversely through the posterior iliac alas, which was connected to the distraction instrumentation. This proved to have harmful effects on sagittal balance. Kostiuk modified this rod, but again the technique was affected by the destruction of the grafts of the posterior iliac crest. Iliosacral screws were used, but these had a high incidence of neural injury. ${ }^{11.12}$

Luque, Galveston, Allen and Ferguson used an altered rod in the iliac ala. This knowledge led to the Galveston rod technique
Table 1. Demographic data.

\begin{tabular}{|c|c|c|c|c|c|c|}
\hline Variables & & $\begin{array}{l}\text { Abs. } \\
\text { Freq. }\end{array}$ & $\begin{array}{r}\text { Rel } \\
\text { freq. }\end{array}$ & Variables & Average & SD \\
\hline \multirow[t]{2}{*}{ Sex } & Female & 12 & $80 \%$ & Age & 57 & 9 \\
\hline & Male & 3 & $20 \%$ & Weight & 94 & 30 \\
\hline \multirow[t]{2}{*}{ Alcoholism } & If & 10 & $66 \%$ & $\begin{array}{l}\text { Time of } \\
\text { surgery. }\end{array}$ & 5 & 1 \\
\hline & Not & 5 & $34 \%$ & Bleeding & 1380 & 178 \\
\hline \multirow[t]{2}{*}{ Smoking } & If & 0 & $0 \%$ & & & \\
\hline & Not & 15 & $100 \%$ & & & \\
\hline \multirow[t]{2}{*}{ Drugs } & If & 0 & $0 \%$ & & & \\
\hline & Not & 15 & $100 \%$ & & & \\
\hline \multirow[t]{2}{*}{ Surgical history } & Yes & 9 & $60 \%$ & & & \\
\hline & No & 6 & $40 \%$ & & & \\
\hline \multirow[t]{2}{*}{ Instrumentation } & Yes & 15 & $100 \%$ & & & \\
\hline & No & 0 & $0 \%$ & & & \\
\hline \multirow[t]{2}{*}{ Bone graft } & Yes & 15 & $100 \%$ & & & \\
\hline & No & 0 & $0 \%$ & & & \\
\hline \multirow[t]{4}{*}{ Diagnosis } & Spondylolisthesis & 6 & $40 \%$ & & & \\
\hline & $\begin{array}{l}\text { Narrow lumbar } \\
\text { canal }\end{array}$ & 4 & $27 \%$ & & & \\
\hline & Herniated disc & 4 & $27 \%$ & & & \\
\hline & $\begin{array}{l}\text { Degenerative } \\
\text { Scoliosis }\end{array}$ & 1 & $6 \%$ & & & \\
\hline
\end{tabular}

for iliac fixation, a technique that was originally described for paralytic deformity of the spine. The rod is inserted into the ilium, just above the sciatic notch, and then rotated into position in the fixation system of L5. ${ }^{13.14}$

The evolution in the placement of the screws has led to a new generation of iliac screws that give better grip in this zone, and which are designed to facilitate the connection and easy integration with the screws of S1 and the rest of the structure.

The complications associated with sacropelvic fixation include vascular, neural and bone problems and pseudoarthrosis. A very convergent S1 screw can damage the artery or middle sacral veins; some excessively divergent or long screws can cause lesions of the artery or internal or common iliac vein; the upper hypogastric plexus can be damaged by long, convergent screws of $\mathrm{S} 1$ through the sacral promontory; and the sacrum can also become fractured through the instrument site, due to stress. ${ }^{11}$

This type of stabilization is achieved through the principle of load sharing and dissipation, and is effective in a wide range of pathologies.

The current generation of iliac instrumentation can easily join the lumbosacral implants, and is safer and more biomechanically sophisticated than the previous instrumentation, besides being a key element in the anchorage of long structures used to correct deformities, especially in the osteoporotic patient. Therefore, this type of instrumentation is of substantial benefit for restoring sagittal balance. ${ }^{11}$

The stability generated by the lumbopelvic instrumentation is achieved through the principle of load sharing and dissipation, which is effective in a wide range of pathologies.

The current generation of iliac instrumentation can easily join lumbopelvicos implants, and is safer and biomechanically more sophisticated than the previous instrumentation, besides being a key element in the anchorage of long instrumentations used to 
correct deformities, especially in the osteoporotic patient. This type of instrumentation is, therefore, of substantial benefit for restoring sagittal balance with the pelvic base fixation.

\section{CONCLUSION}

Based on the experience gained, we can conclude that lumbopelvic fixation is a useful tool, which provides extreme stabilization using screws in the iliac crest with adapt-connector to the axial extension rod and lumbosacrcal constructions both in S1 and S2, in patients who require arthrodesis with extreme variables due to associated characteristics. These include: osteopenia and osteoporosis in both the long instrumentations, particularly in review cases, or in cases of failed lumbar surgery syndrome, as well as in degenerative scoliosis and even in patients with morbid obesity, due to three-dimensional correction, which prevents dimensional loosening of the sacral implants, or lysis in the iliac crests, as often occurs in the "Galveston" type construction through the components and vectors of tension and force. Thus, a powerful, stable pelvic base is built that is used in patients where the surgical anatomy is "weak" due to changes to the implants, both in pseudoarthrosis or larger decompressive complexes, especially in long constructions, always ensuring an arthrodesis technique with sufficient quantity of bone graft, whether autologous or homologous, including the use of support of biological substances as the bone matrix and BMP, and obviously taking care to maintain the sagittal balance to avoid kyphosis of the extreme cephalic end of the instrumentation. The long-term follow-up of our patients has not yet been verified for complete validation of this technical proposal.

All authors declare no potential conflict of interest concerning this article.

\section{REFERENCES}

1. Zheng ZM, Yu BS, Chen H, Aladin DM, Zhang KB, Zhang JF, et al. Effect of iliac screw insertion depth on the stability and strength of lumbo-iliac fixation constructs: an anatomical and biomechanical study. Spine (Phila Pa 1976). 2009;34(16):E565-72.

2. Kelly BP, Shen FH, Schwab JS, Arlet V, Diangelo DJ. Biomechanical testing of a novel fourrod technique for lumbo-pelvic reconstruction. Spine (Phila Pa 1976). 2008;33(13):E400-6.

3. Kwon BK, Elgafy H, Keynan O, Fisher CG, Boyd MC, Paquette SJ, et al. Progressive junctional kyphosis at the caudal end of lumbar instrumented fusion: etiology, predictors, and treatment. Spine (Phila Pa 1976). 2006:31(17):1943-51.

4. Shen FH, Harper M, Foster WC, Marks I, Arlet V. A novel "four-rod technique" for lumbo-pelvic reconstruction: theory and technical considerations. Spine (Phila Pa 1976). 2006;31(12):1395-401.

5. Moshirfar A, Rand FF, Sponseller PD, Parazin SJ, Khanna AJ, Kebaish KM, et al. Pelvic fixation in spine surgery. Historical overview, indications, biomechanical relevance, and current techniques. J Bone Joint Surg Am. 2005;87(Suppl 2):89-106.

6. Schildhauer TA, McCulloch P, Chapman JR, Mann FA. Anatomic and radiographic considerations for placement of transiliac screws in lumbopelvic fixations. J Spinal Disord Tech. 2002;15(3):199-205.
7. Kuklo TR, Bridwell KH, Lewis SJ, Baldus C, Blanke K, Iffrig TM, et al. Minimum 2-year analysis of sacropelvic fixation and L5-S1 fusion using S1 and iliac screws. Spine (Phila Pa 1976). 2001;26(18):1976-83.

8. McCord DH, Cunningham BW, Shono Y, Myers JJ, McAfee PC. Biomechanical análisis of lumbosacral fixation. Spine (Phila Pa 1976). 1992;17(8 Suppl):S235-43.

9. Polly DW Jr, Orchowski JR, Ellenbogen RG. Revision pedicle screws. Bigger, longer shims--what is best? Spine (Phila Pa 1976). 1998:23(12):1374-9.

10. Comstock $\mathrm{CP}$, van der Meulen MC, Goodman SB. Biomechanical comparison of posterior internal fixation techniques for unstable pelvic fractures. J Orthop Trauma. 1996;10(8):517-22.

11. Kostuik JP. Spinopelvic fixation. Neurol India. 2005;53(4):483-8.

12. Harrington DR. The history and development of Harrington Instrumentation. Clin Orthop Relat Res. 1973;(93):110-2.

13. Luque ER. The anatomic basis and development of segmental spinal instrumentation Spine (Phila Pa 1976). 1982;7(3):256-9.

14. Allen BL, Ferguson RL. The Galveston Technique for the L-Rod Instrumentation of the scoliosis. Spine (Phila Pa 1976). 1982;7(3):256-9. 